\title{
THE EDUCATION OF LOVE AND ITS RELEVANCE TO ISLAM AS A RELIGION OF COMPASSION: A Study on the Concept of Mahabbah of Rabi'ah al-Adawiyah
}

\author{
Amir Maliki Abitolkha \\ UIN Sunan Ampel Surabaya, Indonesia \\ E-mail: amir.abitolkha@gmail.com \\ Muhamad Basyrul Muvid \\ Universitas Dinamika Surabaya, Indonesia \\ E-mail: muvid@dinamika.ac.id
}

\begin{abstract}
The concept of love defined by Rabi'ah Al-Adawiyah, known as mababbah, is a situation where love is not meant except for Allah. No one is remembered, longed for, and loved except Him. Love for Him is a representation of the process of riyädah and mujähadah. Education of love in the concept of mababbab is an effort to guide, shape, and educate a servant to become a person who has noble character and has a high spiritual soul to Allah. The relevance of education of love to Islam as a religion of compassion (rahmah) is the goal to fight hatred, envy, enmity, tension, social jealousy, violence, differences, and disputes. All of this is replaced by a sense of love, peace, and harmony among creatures, in the sphere of religion, state, and world. In particular, this article will examine 1) the concept of Rabi'ah Al-Adawiyah's mahabbah, 2) the education of love in the Sufistic dimension of Rabi'ah Al-Adawiyah, and 3) the relevance of love education in the Sufistic dimension of the mahabbah towards Islam as a religion of compassion.
\end{abstract}

Keywords: Mahabbab; Love Education; Islam; Rahmah.

Article history: Received: 11 September 2020; Revised: 24 October 2020; Accapted: 09 November 2020; Available online: 01 March 2021

\section{How to cite this article:}

Abitolkha, Amir Maliki, and Muhamad Basyrul Muvid. "The Education of Love and Its Relevance to Islam as a Religion of Compassion: A Study on the Concept of Mahabbah of Rabi'ah Al-Adawiyah". Religió: Jurnal Studi Agama-agama 11, no. 1 (2021): 1-22. https://doi.org/10.15642/religio.v11i1.1659. 


\section{Introduction}

Love is a state of tremendous feeling buried deep down in the heart (qalb). It makes a person longing for something they loved. It also makes one's life beautiful, peaceful, and harmonious. Someone who loves always spread compassion and affection to others. Love does not discriminate against social class, ethnicity, culture, skin color, or religion. It makes someone feel good in every circumstance, whether poor, rich, sad, or happy. All will be the same if the love has spread into the soul.

Such love is a true love that direct to the Divine order. It is not a blind love that makes someone drunk so that s/he loses their consciousness and forgets the function of their reason, makes them no longer able to distinguish between what is right and what is wrong. ${ }^{1}$ This kind of love is not based on the heart (qalb) but rather on lust (nafs). If love is based on the heart, it will be in line with the values of God. Conversely, if love is based on lust, it will be enslaved and lead the lover astray from the path of truth. ${ }^{2}$

In life, love appears in various forms, through love for the self, spouse, children, wealth, friends, and God for instance. The form of love is attached to the human self. The potential and frequency of love are changing according to the situation and conditions that affect it. Thus, love plays an important role in life. It functions to bind the social relationships among human beings. It also connects humans with God. With true love, human worships God sincerely without any particular intention (là maqsüda illa Alläh), following everything $\mathrm{He}$ commands, avoiding all that He prohibits, and live under His law. When one's love for God has grown, it leads them to righteousness, virtue, and sacrifice for God. ${ }^{3}$

The concept of love in Sufism is also known as mababbah. As quoted by Rosihan Anwar, Umar al-Suhrawardi stated that mababbah is a chain of harmony that binds the Creator to His lover and annihilates the form of the lover to unite with Him. Hence, the lover first mastered all the qualities in themselves, then captured their

\footnotetext{
${ }^{1}$ HP. Wijayanto, Dengan Cinta Aku Hidup Abadi (Yogyakarta: Gama Media, 2001), 12.

${ }^{2}$ Kamaruddin Mustamin, "Konsep Mahabbah Rabi'ah al-Adawiyah," al-Farabi, Vol. 17, No. 1 (2020): 66-76.

3 Abu Bakr Muhammad al-Kalabadzi, Al-Ta'arruf li Madz̧hab Abl al-Tasawuf (Beirut: Dar al-Kutub al-Ilmiyah, 1993), 131.
} 
substance in the grasp of God's order (qadrat-Alläb). ${ }^{4}$ Thus, the soul of a servant contains only the spirit of affection, a love-filled only by divine names. ${ }^{5}$

Mahabbah is a Sufistic dimension renowned by the early mystic women in Islam, Rabi'ah al-Adawiyah, ${ }^{6}$ sometimes also known as Rabi'ah of Basra, referred to her origin of birth, Basra (today, Iraq). Rabi'ah's journey led her to become a Sufi woman whose life was only devoted to God. According to Zawawi Imran as quoted by Sururin, the concept of mababbah is a creative love resulting from the struggle of her faith with life experience rich in meaning, as well as the result of a deep appreciation of the nature of life and persimmonism. ${ }^{7}$

Through this mababbah, Rabi'ah poured out all her longing, love, and devotion to God, so that there is no sense of hate, grudge, and negative thoughts in her soul, but only true love to God. This kind of love, we argue, needs to be developed to become a formal education. We think that if someone is educated by love, one's soul will be avoided from hatred. A true lover wrapped in compassion instead of vindication and an ingrained sense of brotherhood among fellow beings instead of differences. ${ }^{8}$ It is also important to stem extremist movements, radical groups, racism, and intolerance acts that disrupt life and erode the sense of unity among the people. Therefore, this Sufistic-based love needs to be developed into an educational concept that can provide the meaning of education for the society to be human full of love and peace. ${ }^{9}$

${ }^{4}$ Rosihon Anwar and Mukhtar Solihin, Ilmu Tasawuf (Bandung: Pustaka Setia, 2000), 74.

5 Mubassyirah Muhammad Bakry, "Maqamat, Ahwal dan Konsep Mahabbah Ilahiyah Rabi'ah Al-Adawiyah (Suatu Kajian Tasawuf)," Al-Asas, Vol. 1, No. 12, (2018): 95. Read also Abu Hamid Al-Ghazali, Ibyà' 'Ulüm al-Din, Juz IV (Beirut: Dar al-Kutub al-Ilmiyah, 1992), 311.

${ }^{6}$ Abuddin Nata, Akblak Tasamuf (Jakarta: Rajawali Pers, 2011), 214.

7 Sururin, Rabi'ah al Adawiyah Hubb al Illabi (Jakarta: PT Raja Grafindo Persada, 2002), 2. Read also Margareth Smith, "Rabi'ah al-Adawiyah" in H.A.R Gibb \& J.H. Krames, Shorter Encyclopadia of Islam (London: Luzac \& Co, 1961), 463.

8 Ach. Maimun, "Mahabbah dalam Tasawuf Rabi'ah Al-Adawiyah: Apresiasi atas Rintisan Mistik Sejati dalam Islam," Millah: Jurnal Studi Agama, Vol. 3, No. 2 (2016): 172-187; Ida Faridatul Hasanah, "Konsep Ajaran Tasawuf: Studi Perbandingan Pemikiran Al-Ghazali dan Rabi'ah Al-Adawiyah," Attanwir: Jurnal KeIslaman dan Pendidikan, Vol. 11, No. 2 (2020): 61-73.

${ }^{9}$ Department of International \& Transcultural Studies, Fundamental Concepts of Peace Education (Colombia: Columbia University, 2006), 1; Betty A. Reardon, Comprehensive Peace Education: Education for Global Responsibility (New York, Colombia University: 
This kind of love education reflects a true believer who always spread feelings of mutual respect, tolerance, and cooperation. ${ }^{10}$ For a believer, love has a position and a peerless taste. A believer will not feel the sweetness of faith until they feel the warmth of love. Thus, love is a condition of faith. The incarnation of love is the presence of Islam, the religion of compassion (rahmah). Islam contains love between God and His Creation, love for religion, love to fellow beings, ${ }^{11}$ a love to the homeland ${ }^{12}$ and the natural environment. ${ }^{13}$

Thus, we argue that the concept of mababbab in the Sufism of Rabi'ah should be elaborated more in the educational aspects and associated with the concept of Islam as a religion of compassion. Hopefully, the education of love that comes from the Sufi concept of mahabbah can contribute to the lively education in a heterogeneous society. It is important to create a sense of mutual love, respect, and mutual longing which characterizes the mercy of Islam for all beings and nature.

\section{The Concept of Mahabbah in the Sufism of Rabi'ah Al- Adawiyah}

The word mababbab is derived from the Arabic word $a-\underline{b} a-b b a$,

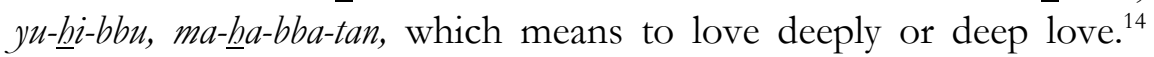
According to al-Qusyairi, mababbah is a state of a noble soul whose form is witnessed by God. ${ }^{15}$ Likewise, Harun Nasution stated that

Teacher College Press, 1988), 11-38; Asmaun Sahlan and Angga Teguh Prastyo, Desain Pembelajaran Berbasis Pendidikan Karakter (Yogyakarta: Ar-Ruzz Media, 2012), 39; Read also Moh. Toriqul Chaer, "Islam dan Pendidikan Cinta Damai," Istawa: Jurnal Pendidikan Islam, Vol. 2, No. 1 (2017): 73-94.

${ }^{10}$ Imam Machalli, "Peace Education dan Deradikalisasi Agama," Jurnal Pendidikan Islam, Vol. 2, No. 1 (2013): 45, https://doi.org/10.14421/jpi.2013.21.41-64.

11 Ibnu Qayyim al Jauziyyah, Penawar Hati yang Sakit, trans. Ahmad Turmudzi (Jakarta: Gema Insani Press, 2003), 12.

12 Muhamad Arif, "Revitalisasi Pendidikan Cinta Tanah Air di Pondok Pesantren Darul Ihsan Menganti Gresik," Jurnal Iqra': Kajian Ilmu Pendidikan, Vol. 3, No. 2 (2018): 277-296.

13 Muhammad Husnur Rofiq and Prastio Surya, "Model Pembentukan Karakter Berbasis Tasawuf Akhlaqi," Ilmuna: Jurnal Studi Pendidikan Agama Islam, Vol. 1, No. 2 (2019), 65-81; Jauhar Fuad, "Pendidikan Karakter dalam Pesantren Tasawuf," Tribakti: Jurnal Pemikiran Keislaman, Vol. 23, No. 1 (2012): 195-204.

${ }_{14}$ Mahmud Yunus, Kamus Arab Indonesia (Jakarta: Hidakarya, 1990), 96.

15 Al-Qusyairi al-Naisabury, Al-Risälah al-Qushairiyah (Mesir: Dar al-Khair, t.t), 318. 
mababbah means love to God, ${ }^{16}$ by embracing obedience to God and hating the attitude of fighting against Him, giving all self to the loved one, and emptying the heart of everything except the beloved, namely God Himself. This signifies that mababbah is a situation in which a servant has reached the level of love and affection to God. This is what Rabi'ah wanted to build.

As the mother of mababbah, ${ }^{17}$ Rabi'ah has the full name of Ummu al-Kha'i bin Ismail al-Adawiyah al-Qaisyiyah and said to have been born in Basra around 95 AH (717 AD). She was a great Muslim saint in Iraq at the time, lived between 717 and $801 \mathrm{AD}$, and died in $185 \mathrm{AH}(796 \mathrm{AD}) \cdot{ }^{18}$ Rabi'ah was once a slave who was later freed. In later life, she worshipped a lot, ${ }^{19}$ repented, and stayed away from worldly life. She lived in simplicity and rejected all material assistance that people gave to her. ${ }^{20}$ In the various prayers she offered, she did not want to accept material things from God. Instead, she lives in a state of asceticism and only wants to be as close as possible to God. ${ }^{21}$

The sincerity of Rabiah in loving God without expecting anything can be seen from her daily behavior, such as her prayers and the poems she chanted. ${ }^{22}$ Hence, it gives a picture that the concept of mababbah is true love to God without expecting His rewards, paradise, mercy, and forgiveness. In other words, her love for God is pure without any modes. ${ }^{23}$ If one expecting paradise, rewards, mercy, and forgiveness for their prayers, then the worship is only because of it, while God is hidden by it. ${ }^{24}$ Rabi'ah's spiritual

${ }^{16}$ Harun Nasution, Falsafah dan Mistisme dalam Islam (Jakarta: Bulan Bintang, 1983), 70.

17 Abuddin Nata, Akblak Tasawuf (Jakarta: Rajawali Pers, 2010), 214.

${ }^{18}$ Kamil Mustafa al-Shaybi, Al-Silah Bayn al-Tasawnuf wa al-Tashayyu' (Cairo: Dar alMa'arif, t.t), 299-300.

${ }^{19}$ Samsul Munir Amin, Ilmu Tasawnf (Jakarta: Amzah, 2012), 243.

${ }^{20}$ Edi Yusuf Ns, "Akhlak Tasawuf Sufi Wanita: Belajar dari Rabi'ah Al-Adawiyah," An-Nur, Vol. 6, No. 2 (2014): 355-369.

21 A. J. Arberry, Pasang Surut Aliran Tasawuf, trans. Bambang Herawan (Bandung: Mizan, 1985), 49; Hamka, Tasawuf Perkembangan dan Pemurniannya (Jakarta: Pustaka Panjimas, 1984), 79; Fariduddin al-Attar, Warisan Para Auliya' (Bandung: Pustaka, 1994), 57; Smith, Rabiah Pergulatan Spiritual Perempuan (Surabaya: Risalah Gusti, 1997), 7.

${ }^{22}$ Harun Nasution, Falsafah dan Mistisme, 72; Arberry, Pasang Surut Aliran Tasawnf, 159.

${ }^{23}$ See Q.S. al-Bayyinah: 5.

${ }^{24}$ Mudaimin, "Konsep Cinta Ilahi (Mahabbah) Rabi'ah Al-Adawiyah," Rausyan Fikr: Jurnal Studi Ilmu Ushuluddin dan Filsafat, Vol. 16, No. 1 (2020): 133-162. 
experience laying down the basis that both men and women have the same opportunity to reach the true love of God. ${ }^{25}$

In Sufism, mababbah is a spiritual state (maqām) achieved by a spiritual walker (sälike) after they reached mushähadah. Nothing is meant, sought, remembered, intended, expected, feared, praised, and loved except God Himself. There is no even a place to hate because if the heart is still attached to someone other than Him, then the love for God is false. Because in the name of love $(\underline{b} u b b)$, there is no place in the heart but the beloved, that is, God. As quoted by Kamil Mustafa, Rabi'ah once said: ${ }^{26}$

"I do not worship God because of fear of Hell, nor I wish for

His Paradise. Because these desires will make me a servant of bad character. So, know that I worship Him because of love $(\underline{b u b b})$ and longing (shauq) to Him."

"Inwardly, to Him you (human) are disobedient.

But in outer self, you declare love (to God).

What a strange symptom this is,

If your love is true and sincere,

Of course, you obey to what He has commanded,

For lovers are always obedient and devoted to the loved ones." 27

Then, Rabi'ah made his most famous love verse as quoted by Shaykh Abu Bakr al-Kalabadzi: ${ }^{28}$

"I love you with two love,

Love because of me, and because of You

Love because of me is a state of ever remembering You

Love because of You is my state of revealing the veil

So that you may appear visible to me

Neither this nor that, praise is not for me

To you, praise is to all."

Another story mentions that she always rejected the proposals of righteous men, saying as quoted by Attar: ${ }^{29}$

"The marriage contract is for the owner of an extraordinary

existence. As for me, it does not exist, because I have no

25 Mohammad Affan, "Semangat Feminisme dalam Pengalaman Spiritual Rabi'ah Al-Adawiyah,” Musawa, Vol. 6, No. 2 (2008): 241.

${ }^{26}$ Al-Syaibi, Al-Silah Bayn al-Tasawnuf wa al-Tashayyu', 36.

27 Abu al-Wafa al-Ghanimi al-Taftazani, Sufi dari Zaman ke Zaman, trans. Ahmad Rofi' Utsmani (Bandung: Pustaka, 1985), 86.

28 Abu Bakar Muhammad al-Kalabadzi, Ta'arruf li Madz̧hab Abl al-Tasammuf (t.tp: Isa al-Bab al-Halabi, 1960), 131.

${ }^{29}$ Fariduddin al-Attar, Tadzkirah al-Auliyä,' 66. 
longer existed and have been detached from myself. I want to be in God and I am entirely His. I live in the shade of His word. The marriage contract must be requested from Him, not from me."

This indicates that the Rabi'ah is already immersed in the awareness of closeness to God. When she was sick, she said to his guests who asked about her illness: "For the God's sake, I do not feel pain because paradise has been shown to me, whereas I long for it in my heart, and I feel that my Lord is jealous of me, then denounce me. He is the one who can make me happy." 30 This is to hint that the love initiated by her is very sincere, so pure, and without expecting anything from her loved ones.

As she said when he prayed: ${ }^{31}$

"O my Lord, drown me in Your love,

So that no one occupies me other than You

My God, the stars in heaven have sparkly, the eyes have asleep, the doors of the palace have been locked, and every lover have been alone with the loved one, and this is me in your presence."

Furthermore, when the dawn is coming, she said: $:^{32}$

"My Lord, the night has passed, and the day is ready to appear, I'm nervous as to whether my practice You accept until I feel happy,

Or do You reject it so that I feel sad,

For your omnipotence, this is what I will do forever

You gave life,

If You had driven me out of Your door, I would not have gone.

For my love for You has filled my heart."

Here, it appears that there is no longer a veil that limits her love for God. Her soul no longer sees her, but what she loves, which is God. A love (mababbah) at this stage is equivalent to gnosis (ma'rifah). However, if ma'rifah is a level of knowledge to God through the heart (qalb), then mababbah is a feeling of closeness to God through love (bubb). ${ }^{33}$ Thus, mababbah is the highest achievement of the Sufis spiritual journey, both in terms of its position and in its definition. If ma'rifah is a level of knowledge to God through the eyes of the heart (basirab), then mababbah is a feeling of closeness with God through

\footnotetext{
30 A.J Arberry, Pasang Surut Aliran Tasawnf, 50.

${ }^{31}$ Ibrahim Basyuni, Nasy'ah al-Tasammuf (Mesir: Dar al-Ma'arif, t.t), 190.

32 Ibid., 190.

33 Jamil, Akblak Tasawuf (Ciputat: Referensi, 2013), 121.
} 
love $(r \bar{u} \underline{h})$. Love grows because knowledge and self-knowledge to God are very clear and deep so that what is seen and felt is no longer just love, but a beloved self. Therefore, according to Al-Ghazali, mababbah is a manifestation of ma'rifah to God. ${ }^{34}$

Thus, the concept of mababbah is love based on the purity of intention and purpose. Not overshadowed by gifts, tests, threats, anxiety, or compulsion. When expressing love to God but by the intention of a gift from Him, then the love is impure. And such an attitude makes God jealous and disappointed. This is the picture of Rabi'ah's love, and we can observe this in every verse of poetry and prayer that she always prays. ${ }^{35}$

Rabi'ah's concept of mababbah can be used as a spiritual stage (maqām) of a salite in measuring how close s/he to God during the spiritual journey. This concept is not easy to do for lay people and the salike without doing the process of tazkiyah al-nafs, riyädab al-nafs, and mujāhadab ila-Alläb solemnly and continuously. ${ }^{36}$ This means that someone who achieved this spiritual stage must go through the process first. If we associate it with the process of surrender ('ubuidiyah) as the main symbol of the human relationship with God, we can see it in terms of one's prayer. The first level of a person in performing prayer is because of obligation and fear of hell. At the next level, ones feels that prayer is a necessity and a form of surrender to God. The higher level of prayer is because of love for God. At this level, only those who have been able to know God deeply (ma'rifah) can achieve it. ${ }^{37}$ This concept can be a reference for the spiritual journey who want to get closer (taqarrub) to God.

\section{The Education of Love in the Concept of Rabi'ah's Mahabbah}

The educational values in the concept and practice of Rabi'ah sufism are valuable for the formation of personality, morality, and spirituality. This can be seen from the attitude shown by Rabi'ah who

\footnotetext{
34 IAIN Sumatera Utara, Pengantar Ilmu Tasawuf (Medan: IAIN Sumut Pers, 1984), 125.

35 Wasalmi, "Mahabbah Dalam Tasawuf Rabi'ah Al-Adawiyah," Sulesana, Vol. 9, No. 2 (2014): 83-85.

36 Muhamad Basyrul Muvid, Strategi dan Metode Kaum Sufi dalam Mendidik Jiwa (Kuningan: Goresan Pena, 2019); Syaikh Abdul Qadir al-Jilani, Al-Fath al-Rabbāni wa al-Faid al-Rahmānì (Beirut: Dar al-Kutub al-Ilmiyah, 2010), 151.

37 Ajibah al-Hasani, Iqädz al-Himam fi Shark al-Hikam (Jeddah: al-Haramain, 1982), 223.
} 
was very devoted ascetic, reflected in his spiritual quality such as wara $\bar{a}$, qanäah, shukr, tawakkal, rid $\bar{a}$, and faqr. Why did she choose to live a life with misery? We argue that it is because the misery brings her out of the pleasures of the world, the glitter of the world that blinds the eyes so that it can be a barrier to her in drawing closer to God, let alone in loving Him. For her, to love God is everything, so that other than Him must be eliminated. This is so-called a perfect love. ${ }^{38}$

The personality shown by Rabi'ah is what made her a great Sufi. Her personality is the influence of her concept of mababbah that she applied in her life. So, she is not restless and fear of anything and anyone, considering what in her soul is a feeling of love-longing for God. Thus, if one's soul is not fostered a deep love to God, then it is certain that a person still has a restless attitude of their fate especially if they live in misery. It is only when Rabi'ah managed to remove all the burdens of her life, her dependence on creatures, and all kinds of obstacles to God, she can do the spiritual journey to God willingly, sincerely, and completely because of God Himself, by multiplying worship and prayers to Him. It is this encouragement of love that makes her irreplaceable from the divine deed. ${ }^{39}$

This means that mababbah can increase the spirituality of humans because if love is ingrained in the soul, it will encourage a person to always be close to the beloved God. So, there is no sense of difficulty, objection, and saturation when worshipping God. This is a sign of a person who managed to feel the favor of sweet worship to God. ${ }^{40} \mathrm{It}$ is through this aspect of personality and spirituality that becomes the focus and foundation of love education. So, it can be said that the education of love in mababbah is the process of educating the soul to be a righteous person, obedient, submissive, and longing for God which all comes down to love in the heart. ${ }^{41}$ Without the existence of

\footnotetext{
38 Nata, Akblak Tasawuf, 214-215; Hamka, Tasawnf Perkembangan, 79; Al-Attar, Tadzkirah al-Auliyaā', 50; Jamil, Akblak Tasawuf, 117.

39 Muhamad Athiyah Khamis, Penyair Wanita Sufi Rabiah al-Adawiyah (Kuala Lumpur: Thinkers Library, 2000), 2-3.

40 Samsul Munir Amin, Ilmu Tasawuf, 243-244; Ibnu Qayyim al-Jauziyyah, Madārij alSälikin baina Manāzil Iyyāka Na’budu wa Iyyäka Nasta’in (Kairo: t.p., 1956), 96.

41 Abd Al-Mun'im Qindil, Rabi'ah al-Adawiyah dan Cinta, trans. Mohd. Sofwan Amrullah and Mohd Royhan Hasbullah (Kuala Lumpur: Pustaka Syuhada, 1997), 95.
} 
love, it is difficult to remember the beloved since true love does not require expressions. ${ }^{42}$

Therefore, in this education of love, one is trained and encouraged to empty their heart from other than God. That what is remembered and intended in this life is only God, not other than Him. ${ }^{43}$ It could be achieved by increasing the sense of servitude through the process of continuous worship and purifying the heart (tarkiyah al-nafs) from various negative things including the encouragement of lust, and always do riya dab al-nasf to weaken the lusts and defeat the seduction of satan, and closed with the process of mujähadah ila-Alläb. ${ }^{44}$ When everything is done well, then one will find real love for God so that the person released all but their beloved God. In other words, they will be an obedient servant. ${ }^{45}$

Thus, mababbab will prevent them from doing negative attitudes and despicable such as ungrateful, ungodly, arrogant, selfish, neglection, radical, intolerance, even perhaps idolatry, and other bad qualities. ${ }^{46}$ The spiritual walker wants to be a servant whom God loves so that what God commands them to do they do it, and what He forbids they leave it behind. ${ }^{47}$ Similarly, when young people fall in love, they will desperately do what their partner wants and give up to leave something that their partner hates. Because they want their beloved partner not to be jealous, disappointed and leave them. ${ }^{48}$

Also, they will always spread compassion, love, and grace to every creature as an implication of his love to the Creator. ${ }^{49}$ Mababbah echoes the meaning in Mu'jam al-Falsafi. Jamil Shaliba said that

42 Mustafa 'Abd al-Raziq, Al-Tașawnf (Beirut: Dar al-Kitab al-Lubnani, 1984), $114-$ 115.

43 Al-Qusyairi al-Naisabury, al-Risälah al-Qushairiyah (Cairo: Dar al-Fikr al-'Arabi, t.t), 320-326; Abdul Mujib and Yusuf Mudzakir, Nuansa-nuansa Psikologi Islam (Jakarta: PT Raja Grafindo Persada, 2001), 259.

44 Mohammad Saifullah Aziz Senali, Risalah Memahami Ilmu Tasawuf(Surabaya: Terbit Terang, 1998), 87-94; Samsul Munir, Ilmu Tasawuf, 24-27.

45 Ibrahim Basyuni, Nash'ah al-Tasawuf, 193.

46 Muhamad Hamzah, "Mahabbah dan Deradikalisasi: Pendekatan Tasawuf," (Riau: Undergraduate thesis-UIN Sultan Syarif Kasim, 2020).

47 Jalaluddin Rahmat, The Road to Allah (Bandung: Mizan, 2007), 1.

48 Abdullah bin Alwi bin Muhammad al-Haddad, Risälah al-Mu'āwanah, trans. Ainul Choirry Suchaimi (Surabaya: al-Hidayah, t.t), 209-211.

49 Wahyudi Setiawan, et.al, "Mahabbah as Peak Experiences in Positive Psychology", International Seminar on Islamic Education (2017), 315-316 and 322. Read also Ujam Jaenudin, Psikologi Transpersonal (Bandung: Pustaka Setia, 2012).

49 Jamil Shaliba, al-Mu'jam al-Falsafi (Mesir: Dar al-Kitab, 1978), 439. 
malhabbah is the opponent of al-bughd (hate). ${ }^{50}$ Thus, the soul instilled in the education of love is a feeling of love, compassion, tenderness, harmony, and virtue of life. Eliminating all other hateful, vengeful, angry, and bad qualities, ${ }^{51}$ so that what appears in his behavior is a noble attitude. ${ }^{52}$ This is one of the essences of love education in the Sufistic dimension of Rabi'ah.

Furthermore, the education of love in mababbah also forms one's spiritual qualities besides forming a personality. ${ }^{53}$ Through the education of love in the concept of mahabbah, one will be educated towards a spiritual atmosphere that is full of solemnity, focus, and total concentration in remembering, communicating, surrendering, and pouring out all the contents of the heart to God. ${ }^{54}$ The education of love in mababbah emphasizes the sense (dranq) which is placed in qalb (heart) connected to the names of God. This is what makes the heart pure, sincere in drawing near to Him and in dealing with all the fate from Him. That is, this position is a sign that the sense of spirituality in the soul is already at the highest and reaches gnosis (ma'rifab). This is the ultimate goal of love education which is how a servant can be as close as possible spiritually ${ }^{55}$ so that one can know and the substance of the beloved. ${ }^{56}$

In the education of love based on mababbah, there are noble values that can be used as a foothold and reference in life. Among them are (1) sincerity, (2) compassion, (3) surrender, (4) obedience, (5) earnestness, (6) continuity, (8) loyalty, (9) wisdom, and (10)

\footnotetext{
50 Ibid., 439.

51 Siti Asiah Humdan, "The Concept of Mababbab: Perspective of Rabiatul Adawiyah," Jurnal AlifLam: Journal of Islamic Studies and Humanities, Vol. 1, No. 1 (2020): 31-44.

52 Adibah binti Muhtar, "The theme of Mahabbatullah (God Loving) in Rabi'ah AlAdawiyah Mysticism: an Analytical Study," (Gombak: Thesis-International Islamic University Malaysia, 2002), 101-117.

${ }^{53}$ Rosif, "Pendidikan Etika dan Kepribadian: Studi atas Pemikiran Sayyed Naquib al Attas dan Ibnu Miskawayh," in Antologi Kajian Islam, ed. Husein Aziz, et al. (Surabaya: Pascasarjana UIN Sunan Ampel, 2016), 59.

${ }^{54}$ Muhammad Amri, "Perspektif Kaum Sufi tentang Cinta Tuhan," Al-Hikmah: Journal for Religious Studies, Vol 14, No. 1 (2013): 82-92.

55 Arrasyid, "Konsep-konsep Tasawuf dan Relevansinya dalam Kehidupan," ElAfkar: Jurnal Pemikiran Keislaman dan Tafsir Hadits, Vol. 9, No. 1 (2020): 48-65.

${ }^{56}$ Umar Abu Hafs Al-Suhrawardi, 'Awärif al-Ma'ärif (Singapura: Sulaiman Mar'i, t.t), 313; A. Rivay Siregar, Tasawnf dan Sufisme Klasik. ke Neo-Sufisme (Jakarta: Raja Grafindo Persada, 1999), 57-58; Harun Nasution, Islam Ditinjau dari Berbagai Aspeknya (Jakarta: UI Press, 2008), 76.
} 
laughter $(\operatorname{taw} \bar{a} \underline{d} u)$. These values are a representation of love education in the concept of Rabi'ah's mababbah. Hence, it teaches the importance of sincerity in any case, especially the matter of worship to God, and compassion that must be poured to the Creator so that one become a loving person, ${ }^{57}$ give up everything to Him, servitude as a form of obedience, worship, and righteous deeds to Him as a form of earnestness in drawing closer to Him, and as a form of love to Him. ${ }^{58}$ Continuity (istiqamah) is an energy to always be in His way. Sincerity is a force so as not to stop to love Him, submit to all His commands and prohibitions, faithful as a real manifestation that will not leave Him (shirk) and will not make Him jealous with our deviant behavior, ${ }^{59}$ wise as self-control to always be careful in acting, behave, and speak, and finally surrender (tawädu) as a description that this self has nothing, not as noble as loved, and not as holy as Him, ${ }^{60}$ so that there is no pride to the self because God is the almighty. ${ }^{61}$

These values are appropriate if applied to the education system as a basis and reference in speaking and behaving, besides worshipping God. With this kind of love education, people will behave according to these concepts because the essence of love education is to realize a spiritual and socially pious human being, in hope of spreading peace, harmony, brotherhood, and spirit in the work of virtue and the way to the truth. ${ }^{62}$

57 Adi Fadli, "Belajar Cinta Plus dari Rabi'ah Al-Adawiyah," El-Hikam, Vol. 4, No. 1 (2011): 137-155.

58 Hasnawati, "Paham Mahabbah dan Ma'rifah dalam Tasawuf Islam," Al-Qalb: Jurnal Psikologi Islam, Vol. 6, No. 2 (2015): 100-108; Yayan Mulyana, "Konsep Mahabbah Imam At-Tustari (200-283)," Syifa al-Qulub, Vol. 1, No. 2 (2017): 113121.

${ }^{59}$ Rahmawati, "Rabiatul Adawiyah dan Pemikirannya," Al-Munzir, Vol. 10, No. 1 (2018): 97-112.

${ }^{60}$ Fikri Mahzumi, "Konsep Cinta Sufi Rabi’ah Al-Adawiyah," Miyab: Jurnal Studi Islam, Vol. 11, No. 2 (2017): 217-238.

61 Athoillah Islamy, "Dialectic Motivation, Behavior and Spiritual Peak Experience in the Perspective of Islamic Psychology," Alfuad: Jurnal Sosial Keagamaan, Vol. 3, No. 2 (2019): 35-46.

${ }^{62}$ Rahmi Damis, "Al-Mahabbah dalam Pandangan Sufi," Sulesana: Jurnal Wawasan Keislaman, Vol. 6, No. 1 (2011): 1; Umma Farida, "Tasawuf Cinta dan Relevansinya dengan Kesempurnaan Manusia Menurut Abd Al-Karim Al-Jilli," Esoterik, Vol. 1, No. 1 (2015); Ahmad Badwi, "Metode Dalam Mencapai Kesufian (Perkembangan Tasawuf dan Maqamat dalam Ilmu Tasawuf)," Ash-Shababah, Vol. 3, No. 1 (2017): 101-106; Muzakkir, "Toleransi Beragama dan Mahabbah dalam Perspektif Sufi," Jurnal Theologia, Vol. 23, No. 1 (2017): 125-139. 


\section{The Relevance of Mahabbah to Islam as the Religion of Compassion}

Love Education contained in mababbah relates to the concept of Islam as a religion of compassion. This considers that both mahabbah and rahmah has the same purpose in spreading love, respect, and embrace each other as well as fellow beings, ${ }^{63}$ and strongly oppose intolerance, radicalism, racism, discrimination, terrorism, and other forms of anarchy that concern differences, diversity, unity, and peace of life. The Sufi saint put forward compassion and love to others ${ }^{64}$ so that the concept of love education in the dimension of love is precisely synergized with the concept of Islam as a religion of compassion.

The above purpose is a representation of the education of love and the concept of Islam as a religion of compassion that reflects the attitude of a true believer. As Ibn Jauziyah argued that a believer will not feel the sweetness of faith until they feel the warmth of love. ${ }^{65}$ One must have love as a condition of perfect faith. The incarnation of love is the presence of Islam, a religion full of compassion for the universe. As Allah has said, "We have not sent you except as a mercy to the worlds." (QS. 21:107).

Munir explains that the above verse is saying that Muhammad is not revealed to the people except only as a mercy for all nature. That is because what has been sent down to Muhammad is the causation of the happiness of the others. ${ }^{66}$ The preaching (da'wa) of Islam is done with tenderness and facilitates interaction, not with bad morals, harsh character, and a stubborn heart. ${ }^{67}$ As with the concept of love education in the Sufistic dimension of mababbah makes the morality of God the main reference in behaving so it influences the formation of a noble personality. ${ }^{68}$

This confirms that Islam as a mercy for all nature is manifested by conscientiousness, gentleness in associating, and firmness in

\footnotetext{
${ }^{63}$ Muh. Amin Syukur, Tasawnf Bagi Masyarakat Modern (Yogyakarta: Pustaka Pelajar, 2005), 67.

${ }^{64}$ Muzakkir, “Toleransi Beragama...”, 125.

${ }^{65}$ Ibnu Qayyim al-Jauziyyah, Penawar Hati yang Sakit, 12.

66 Wahbah Zuhaili, Al-Tafsir al-Munir fi al-'Aqidah wa al-Shariah wa al-Manhaj (Damaskus: Dar al Fikr, 2009), 155.

${ }^{67}$ Ibid., 467-469.

68 Muhammad Qorib, Lentera Kasih Sayang: Membentang Ukhuwah Menggapai Jannah (Jakarta: t.p., 2007).
} 
enforcing the rules. The increased spirituality, social justice, happiness of all people, and dignity of humanity are the main concern of Islam as a religion of mercy and compassion. This is exemplified by the Prophet Muhammad during his life in establishing the religion of God with tenderness and friendliness so that Islam can be accepted and developed to this day. ${ }^{69}$ The education of love with the concept of mababbah is trying to educate the community to always establish a good social relationship. ${ }^{70}$ Thus, between Islam as a religion of rabmah and mababbah as the basis of love, both are the foundation of the social and spiritual harmony in life.

This fact signifies that Islam has a very important function for the continuity of human life that is heterogeneous, namely as a religion of peace, compassion, and love to all fellow beings regardless of the identity, all are created by God and surrender to Him. Diversity is a nature that must continue to be cultivated into unity instead of division, friendship instead of hostility, and harmony instead of prolonged conflict. This is also in line with the Sufistic concept that all are beings of God that must be loved and respected. That is why the toleration of Sufis is very high. ${ }^{71}$

Similarly, Moch Tolhah argues that Islam which means the religion of peace, safe, surrender, submission, and obedience contains teachings to create peace, harmony, safety, and welfare for mankind in particular and all the creation of God in general, ${ }^{72}$ instead of bringing and creating disasters or damage on the earth. The presence of Islam is a mercy and not a religion of disaster. This is an indicator that Islam in theoretically and practically is a true religion of compassion, always spreads peace, harmony, and prosperity on the earth. It is also a representation of the education of love in the concept of mababbab of Rabi'ah. In other words, there is a close relationship between Islam as a religion of mercy and love education in mababbah. Both aim to create conditions of peace, compassion, love, and brotherhood across religions, culture, tribes, and nations.

\footnotetext{
${ }^{69}$ Machasin, Islam Dinamis, Islam Harmonis (Yogyakarta: LKIS, 2012), 224-225.

70 Fatimah Usman, Wabdat al-Adyan: Dialog Pluralisme Agama (Yogyakarta: LKiS, 2004).

${ }^{71}$ Robert Frager, Heart, Self and Soul: The Sufi Psychology of Growth, Balance and Harmony (Wheaton, Illonis: Quest Books, Theosophical House, 1999), ix-x.

72 Moch Tolhah, et.al, Pendidikan Agama Islam Untuke Perguruan Tinggi Umum (Surabaya: ITATS, 2012), 82.
} 
Both also address differences with wisdom ${ }^{73}$ and not with contention. ${ }^{74}$

Through the understanding of Islam as a religion of compassion and love education in the concept of mababbah, every human being will be wise and moderate (wasatiyah) and put forward an attitude of tolerance (tasamub). In essence, moderation (wasatizah) is an intermediary. It is not radical nor liberal, but a middle way. It plays an important role in mediation and equality. Wasatiyah is a representation of justice, balance, diversity, moderation, and the counter of extremism. The concept of wasatiyah in Islam refers to the principles of tawassut (middle), tasämub (tolerance), tawärun (balanced), i'tidäl (justice), and iqtisād (humble). Thus, the attitude of wasatiyah is also called "a just people" or "a just community". 75

The relevance of love education and Islam as a religion of compassion is a strong connection to remove the blowing of hatred, malevolence, hostility, tension, social jealousy, violence, differences, and disputes between Muslims, human beings, nations, and tribes. ${ }^{76}$ Replace all of that with love, compassion, peace, and harmony, harboring all differences that can create hostility and disharmonization in the middle of life and foster feelings of affection and love amid a homogenous society.

This is an affirmation that Islam is present as a religion of peace and compassion, not of war and rebellion. The idea of indigenization of Islam (pribumisasi Islam) by Abdurrahman Wahid and the secularization theory carried by Nurcholis Majid was nothing but to display a tolerant and loving face of Islam. This is an attempt to "reconcile" Islam with local cultures so that the local culture is maintained. Therefore, Wahid strongly condemned religious traditions or groups that use violence in the name of Islam. ${ }^{77}$

73 Sung Min Kim., J.B. Banawiratma and Dicky Sofjan, "Religious Pluralism Discourse in Public Sphere of Indonesian: A Critical Application of Communicative Action Theory to Inter-religious Dialogue," Religio: Jurnal Studi Agama-agama, Vol. 10, No. 2 (2020): 158-188, https://doi.org/10.15642/religio.v10i2.1307.

74 James A Becford, Social Theory and Religion (Cambridge: Cambridge University Press, 2003).

${ }^{75}$ Masduki Duriyat, Islam Majemuk (Yogyakarta: Pustaka Pelajar, 2019), xii.

76 Roger Boase, Islam and Global Dialogue: Religious Pluralism and the Pursuit of Peace (Burlington: Ashgate, 2005).

77 M Syafi'i Anwar, "Islamku, Islam Anda, Islam Kita, Membingkai Potret Pemikiran Politik KH Abdurrahman Wahid," in in Abdurrahman Wahid, Islamku, 
Similarly, the emergence of Islam Nusantara (Islam in Archipelago) is popular in Indonesia today. It is a sign that Islam is beautiful, assimilate, friendly, polite, respectful of local culture, and not extreme. Such terms are reinforcement and proof that Islam is indeed a religion of compassion, mercy, love, and brotherhood. This is the true face of Islam, both existentially and essentially. ${ }^{78}$

Thus, the education of love and the mercy of Islam are interconnected. Both aim to maintain peace, security, unity, harmony, tranquility, and the development of Islam. Through the education of love, a person is guided and educated to become a human being who has a sense of love, submissive, and obedient to God. One also has compassion for fellow beings, regardless of religious, political, cultural, and racial differences. While Islam as a religion of mercy serves to create peace, brotherhood, harmony, and tranquility for all nature and this is what Muslims must do to carry out what is the function and purpose of Islam. If one practices both, Islam will manifest as a calm and peaceful religion.

\section{Conclusion}

The education of love in the concept of malabbah of Rabi'ah and its relevance to Islam as a religion of mercy leads to three conclusions. First, mababbah is a spiritual condition in which one has reached unity with God. Mababbah is equal to ma'rifah. Hence, there is nothing but God the beloved. A Love to God is a representation of the process of riya da ah and mujähadah, a feeling of total surrender to Him. Mababbah is a concept of a true love who expects no reward, mercy, paradise, and fear of hell.

Second, the education of love in the concept of mahabbah as practiced and demonstrated by Rabi'ah is an effort to guide, shape, and educate a person into devoted human beings with a noble character and a high spiritual soul towards God. Through this kind of personality, one is expected to spread peace, love, and harmony to

Islam Anda, dan Islam Kita, Agama Masyarakat Negara Demokrasi (Jakarta: The Wahid Institute, t.t), xxv.

78 TIM PW LBM NU Jatim, Islam Nusantara (Surabaya: PW LTN NU-PW LBM NU Jatim, 2018), 5; M. Hasyim Asy'ari, Risalah Ablussunnah wa al-Jama'ah (Jombang: Maktabah al-Turats al-Islami, $1418 \mathrm{H})$, 9; Abu al-Fadl as-Senori al-Tubani, Ablā alMusämarah fi Hikeāyah al-Auliyä' al-Ashrab (Bangilan Tuban: Majlis al-Ta'lif wa al Khaththath, t.t), 23-24. 
every human being in their surroundings. And through a high spiritual feeling towards God, one can live calmly, accept all His provisions with gratitude and patient, and worship Him as the only purpose.

Third, the relevance of love education with Islam as a religion of compassion (rabmah) is the interconnection of both objectives to erase hatred, malevolence, hostility, tension, social jealousy, violence, and disputes among Muslims and fellow human beings across nations. All are replaced with love, compassion, peace, harmony, and intimacy.

\section{References}

Affan, Mohammad. "Semangat Feminisme dalam Pengalaman Spiritual Rabi'ah Al-Adawiyah.” Musawa, Vol. 6, No. 2 (2008). Al-Attar, Fariduddin. Warisan Para Auliya'. Bandung: Pustaka, 1994.

Al-Ghazali, Abu Hamid. Ihyaà' Ulüm al-Din. Beirut: Dar al-Kutub alIlmiyah, 1992.

Al-Haddad, Abdullah bin Alwi bin Muhammad. Risälah al-Mu'āwanah, trans. Ainul Choirry Suchaimi. Surabaya: al-Hidayah, t.t.

Al-Hasani, Ajibah. Iqädz al-Himam fi Shark al-Hikam. Jeddah: alHaramain, 1982.

Al-Jauziyyah, Ibnu Qayyim. Madärij al-Sälikìn baina Manäzil Iyyäka Na'budu wa Iyyäka Nasta’in. Cairo: t.p., 1956.

Al-Jauziyyah, Ibnu Qayyim. Penawar Hati yang Sakit, trans. Ahmad Turmudzi. Jakarta: Gema Insani Press, 2003.

Al-Jilani, Syaikh Abdul Qadir. Al-Fath al-Rabbāni wa al-Faid al-Rahmāni. Beirut: Dar al-Kutub al-Ilmiyah, 2010.

Al-Kalabadzi, Abu Bakr Muhammad. Al-Ta'arruf li Madzhab Abl alTasannuf. Beirut: Dar al-Kutub al-Ilmiyah, 1993.

Al-Qusyairi, Al-Naisaburi. Al-Risälah al-Qushairiyah. Cairo: Dar al-Fikr al-'Arabi, t.t.

Al-Raziq, Mustafa 'Abd. Al-Tasawnf. Beirut: Dar al-Kitab al-Lubnani, 1984.

Al-Shaybi, Kamil Mustafa. Al-Silah Bayn al-Tasawwuf wa al-Tashayyu'. Cairo: Dar al-Ma'arif, t.t.

Al-Suhrawardi, Umar Abu Hafs. 'Awārif al-Ma'ärif. Singapura: Sulaiman Mar'i, t.t.

Al-Taftazani, Abu al-Wafa al-Ghanimi. Sufi dari Zaman ke Zaman, trans. Ahmad Rofi' Utsmani. Bandung: Pustaka, 1985.

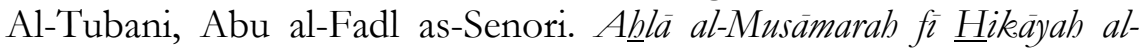
Auliyä' al-Ashrab. Tuban: Majlis al-Ta'lif wa al-Khaththath, t.t. 
Amin, Samsul Munir. Ilmu Tasawuf. Jakarta: Amzah, 2012.

Amri, Muhammad. "Perspektif Kaum Sufi tentang Cinta Tuhan." AlHikmab: Journal for Religious Studies, Vol 14, No. 1 (2013).

Anwar, M Syafi'i. "Islamku, Islam Anda, Islam Kita, Membingkai Potret Pemikiran Politik KH Abdurrahman Wahid." In Abdurrahman Wahid. Islamku, Islam Anda, dan Islam Kita, Agama Masyarakat Negara Demokrasi. Jakarta: The Wahid Institute, t.t.

Anwar, Rosihon and Solihin, Mukhtar. Imu Tasawuf. Bandung: Pustaka Setia, 2000.

Arberry, A. J. Pasang Surut Aliran Tasawuf, trans. Bambang Herawan. Bandung: Mizan, 1985.

Arif, Muhamad. "Revitalisasi Pendidikan Cinta Tanah Air di Pondok

Pesantren Darul Ihsan Menganti Gresik." Jurnal Iqra': Kajian Ilmu Pendidikan, Vol. 3, No. 2 (2018).

Arrasyid. "Konsep-konsep Tasawuf dan Relevansinya dalam Kehidupan." El-Afkar: Jurnal Pemikiran Keislaman dan Tafsir Hadits, Vol. 9, No. 1 (2020).

Asy'ari, M. Hasyim. Risalah Ablussunnah wa al-Jama'ah. Jombang: Maktabah al-Turats al-Islami, $1418 \mathrm{H}$.

Badwi, Ahmad. "Metode Dalam Mencapai Kesufian (Perkembangan Tasawuf dan Maqamat dalam Ilmu Tasawuf." Ash-Shahabah, Vol. 3, No. 1 (2017).

Bakry, Mubassyirah Muhammad. "Maqamat, Ahwal dan Konsep Mahabbah Ilahiyah Rabi'ah Al-Adawiyah (Suatu Kajian Tasawuf)." Al-Asas, Vol. 1, No. 12, (2018).

Basyuni, Ibrahim. Nasy'ah al-Tasammuf. Mesir: Dar al-Ma'arif, t.t.

Becford, James A. Social Theory and Religion. Cambridge: Cambridge University Press, 2003.

Boase, Roger. Islam and Global Dialogue: Religious Pluralism and the Pursuit of Peace. Burlington: Ashgate, 2005.

Chaer, Moh. Toriqul. "Islam dan Pendidikan Cinta Damai." Istawa: Jurnal Pendidikan Islam, Vol. 2, No. 1 (2017).

Damis, Rahmi. "Al-Mahabbah dalam Pandangan Sufi." Sulesana: Jurnal Wawasan Keislaman, Vol. 6, No. 1 (2011).

Department of International and Transcultural Studies. Fundamental Concepts of Peace Education. Colombia: Columbia University, 2006.

Duriyat, Masduki. Islam Majemuk. Yogyakarta: Pustaka Pelajar, 2019. Fadli, Adi. "Belajar Cinta Plus dari Rabi'ah Al-Adawiyah." El-Hikam, Vol. 4, No. 1 (2011). 
The Education of Love and Its Relevance to Islam As a Religion of Compassion: A Study on the Concept of Mahabbah of Rabi'ah Al-Adawiyah

Farida, Umma. "Tasawuf Cinta dan Relevansinya dengan Kesempurnaan Manusia Menurut Abd Al-Karim Al-Jilli." Esoterik, Vol. 1, No. 1 (2015).

Frager, Robert. Heart, Self and Soul: The Sufi Psychology of Growth, Balance and Harmony. Wheaton, Illinois: Quest Books, Theosophical House, 1999.

Fuad, Jauhar. "Pendidikan Karakter dalam Pesantren Tasawuf." Tribakti: Jurnal Pemikiran Keislaman, Vol. 23, No. 1 (2012).

Hamka. Tasawnf Perkembangan dan Pemurniannya. Jakarta: Pustaka Panjimas, 1984.

Hamzah, Muhamad. "Mahabbah dan Deradikalisasi: Pendekatan Tasawuf." Riau: Undergraduate thesis-UIN Sultan Syarif Kasim, 2020.

Hasanah, Ida Faridatul. "Konsep Ajaran Tasawuf: Studi Perbandingan Pemikiran Al-Ghazali dan Rabi'ah Al-Adawiyah." Attanwir: Jurnal KeIslaman dan Pendidikan, Vol. 11, No. 2 (2020).

Hasnawati. "Paham Mahabbah dan Ma'rifah dalam Tasawuf Islam." Al-Qalb: Jurnal Psikologi Islam, Vol. 6, No. 2 (2015).

Humdan, Siti Asiah. "The Concept of Mababbab: Perspective of Rabiatul Adawiyah." Jurnal AlifLam: Journal of Islamic Studies and Humanities, Vol. 1, No. 1 (2020).

IAIN Sumatera Utara, Pengantar Ilmu Tasawnf (Medan: IAIN Sumut Press, 1984.

Islamy, Athoillah. "Dialectic Motivation, Behavior and Spiritual Peak

Experience in the Perspective of Islamic Psychology." Alfuad: Jurnal Sosial Keagamaan, Vol. 3, No. 2 (2019).

Jaenudin, Ujam. Psikologi Transpersonal. Bandung: Pustaka Setia, 2012.

Jamil. Akblak Tasawnf. Jakarta: Referensi, 2013.

Khamis, Muhamad Athiyah. Penyair Wanita Sufi Rabi'ah al-Adawiyah.

Kuala Lumpur: Thinkers Library, 2000.

Kim, Sung Min, Banawiratma and Sofjan, Dicky. "Religious Pluralism

Discourse in Public Sphere of Indonesian: A Critical

Application of Communicative Action Theory to Inter-religious

Dialogue." Religio: Jurnal Studi Agama-agama, Vol. 10, No. 2 (2020): 158-188, https://doi.org/10.15642/religio.v10i2.1307.

Machalli, Imam. "Peace Education dan Deradikalisasi Agama." Jurnal Pendidikan Islam, Vol. 2, No. 1 (2013).

Machasin. Islam Dinamis, Islam Harmonis. Yogyakarta: LKIS, 2012. 
Mahzumi, Fikri. “Konsep Cinta Sufi Rabi'ah Al-Adawiyah.” Miyah: Jurnal Studi Islam, Vol. 11, No. 2 (2017).

Maimun, Ach. "Mahabbah dalam Tasawuf Rabi'ah Al-Adawiyah: Apresiasi atas Rintisan Mistik Sejati dalam Islam." Millah: Jurnal Studi Agama, Vol. 3, No. 2 (2016).

Mudaimin. "Konsep Cinta Ilahi (Mahabbah) Rabi'ah Al-Adawiyah." Rausyan Fikr: Jurnal Studi Ilmu Usbuluddin dan Filsafat, Vol. 16, No. 1 (2020).

Muhtar, Adibah binti. "The theme of Mahabbatullah (God Loving) in Rabi'ah Al-Adawiyah Mysticism: an Analytical Study." Gombak: Thesis-International Islamic University Malaysia, 2002.

Mujib, Abdul and Mudzakir, Yusuf. Nuansa-nuansa Psikologi Islam. Jakarta: PT Raja Grafindo Persada, 2001.

Mulyana, Yayan. "Konsep Mahabbah Imam At-Tustari (200-283)." Syifa al-Qulub, Vol. 1, No. 2 (2017).

Mustamin, Kamaruddin. "Konsep Mahabbah Rabi'ah al-Adawiyah." al-Farabi, Vol. 17, No. 1 (2020).

Muvid, Muhamad Basyrul. Strategi dan Metode Kaum Sufi dalam Mendidik Jiwa. Kuningan: Goresan Pena, 2019.

Muzakkir. "Toleransi Beragama dan Mahabbah dalam Perspektif Sufi." Jurnal Theologia, Vol. 23, No. 1 (2017).

Nasution, Harun. Falsafah dan Mistisme dalam Islam. Jakarta: Bulan Bintang, 1983.

Nasution, Harun. Islam Ditinjau dari Berbagai Aspeknya. Jakarta: UI Press, 2008.

Nata, Abuddin. Akblak Tasamuf. Jakarta: Rajawali Pers, 2010.

Nata, Abuddin. Akblak Tasawuf. Jakarta: Rajawali Pers, 2011.

Qindil, Abd Al-Mun'im. Rabi'ah al-Adawiyah dan Cinta, trans. Mohd. Sofwan Amrullah and Mohd Royhan Hasbullah. Kuala Lumpur: Pustaka Syuhada, 1997.

Qorib, Muhammad. Lentera Kasih Sayang: Membentang Ukhuwah Menggapai Jannah. Jakarta: t.p.

Rahmat, Jalaluddin. The Road to Allah. Bandung: Mizan, 2007.

Rahmawati. "Rabiatul Adawiyah dan Pemikirannya." Al-Munzir, Vol. 10, No. 1 (2018).

Reardon, Betty A. Comprehensive Peace Education: Education for Global Responsibility. New York, Colombia University: Teacher College Press, 1988. 
Rofiq, Muhammad Husnur and Surya, Prastio. "Model Pembentukan Karakter Berbasis Tasawuf Akhlaqi." Ilmuna: Jurnal Studi Pendidikan Agama Islam, Vol. 1, No. 2 (2019).

Rosif. "Pendidikan Etika dan Kepribadian: Studi atas Pemikiran Sayyed Naquib al Attas dan Ibnu Miskawayh." In Antologi Kajian Islam, ed. Husein Aziz, et al. Surabaya: Pascasarjana UIN Sunan Ampel, 2016.

Sahlan, Asmaun and Prastyo, Angga Teguh. Desain Pembelajaran Berbasis Pendidikan Karakter. Yogyakarta: Ar-Ruzz Media, 2012.

Senali, Mohammad Saifullah Aziz. Risalah Memahami Ilmu Tasawuf. Surabaya: Terbit Terang, 1998.

Setiawan, Wahyudi. et.al, "Mahabbah as Peak Experiences in Positive Psychology." Paper presented in International Seminar on Islamic Education (2017)

Shaliba, Jamil. al-Mu'jam al-Falsafi. Mesir: Dar al-Kitab, 1978.

Siregar, A. Rivay. Tasawuf dan Sufisme Klasike ke Neo-Sufisme. Jakarta: Raja Grafindo Persada, 1999.

Smith, Margareth. "Rabi'ah al-Adawiyah" in Gibb, H.A.R and Krames, J.H. Shorter Encyclopadia of Islam. London: Luzac \& Co, 1961.

Smith, Rabiah Pergulatan Spiritual Perempuan. Surabaya: Risalah Gusti, 1997.

Sururin, Rabi'ab al Adawiyah Hubb al Illabi. Jakarta: PT Raja Grafindo Persada, 2002.

Syukur, Muh. Amin. Tasawuf Bagi Masyarakat Modern. Yogyakarta: Pustaka Pelajar, 2005.

TIM PW LBM NU Jatim. Islam Nusantara. Surabaya: PW LTN NUPW LBM NU Jatim, 2018.

Tolhah, Moch, et.al. Pendidikan Agama Islam Untuk Perguruan Tinggi Umum. Surabaya: ITATS, 2012.

Usman, Fatimah. Wabdat al-Adyan: Dialog Pluralisme Agama. Yogyakarta: LKiS, 2004.

Wasalmi. "Mahabbah Dalam Tasawuf Rabi'ah Al-Adawiyah." Sulesana, Vol. 9, No. 2 (2014).

Wijayanto, HP. Dengan Cinta Aku Hidup Abadi. Yogyakarta: Gama Media, 2001.

Yunus, Mahmud. Kamus Arab Indonesia. Jakarta: Hidakarya, 1990.

Yusuf, Edi. "Akhlak Tasawuf Sufi Wanita: Belajar dari Rabi'ah AlAdawiyah.” An-Nur, Vol. 6, No. 2 (2014). 
Amir Maliki Abitolkha, Muhamad Basyrul Muvid

Zuhaili, Wahbah. Al-Tafsir al-Munir fì al-'Aqidah wa al-Shari'ah wa alManhaj. Damaskus: Dar al Fikr, 2009. 